\title{
Keep calm and carry on: A crisis communication study of Cadbury and McDonalds
}

\author{
Achyut TELANG \\ IBS Hyderabad, Telangana, India \\ E-mail: achyutktelang@ibsindia.com
}

\section{Amruta DESHPANDE}

\author{
IBS Hyderabad, Telangana, India
}

\begin{abstract}
Many organizations, at some point or another, have to face a crisis situation. In that scenario, the way in which the organization communicates makes or breaks the organization's success in dealing with the crisis. Especially after the emergence of the social media, the impact of crisis communication on the process of successful crisis management has become even greater than before. Organizations have to take the initiative, to be proactive and create a plan for crisis communication. This paper is focused on the comparative study of the communication approaches followed by Cadbury and McDonalds during a period when the companies were dealing with a crisis. The findings of the content analysis show that a company should respond to the crisis as quickly as possible to avoid loss in terms of sales. The initial statement of the companies during a crisis should be clear, positive and through the right channel to help the company regain its reputation on the market. Advertising is the best way to convey the message across the world because the crisis situation that has come up in one market can soon catch-up in the other markets where the company operates. The company has to connect with the consumers on emotional grounds because the crisis breaks down the faith of the consumers in the company. The recovery actions that support the statements also play an important role during the crisis situation. By following the above-mentioned communication strategies, organizations can achieve damage control as well as turn the crisis into an opportunity to grow.
\end{abstract}

Keywords: crisis communication strategies, organizational communication, public relations, Cadbury, McDonalds.

Please cite the article as follows: Telang, A. and Deshpande, A. (2016), "Keep calm and carry on: A crisis communication study of Cadbury and McDonalds", Management \& Marketing. Challenges for the Knowledge Society, Vol. 11, No. 1, pp. 371-379, DOI: 10.1515/mmcks-2016-0003.

\section{Introduction}

With the increase in media coverage and in the level of people's sensitivity to public issues, every company's employee must know how to communicate during a crisis situation. A crisis can be defined as a situation which has undesirable results for an organization (Coombs, 1999). Crisis communication is the communication between an organization and the public during, after or before the critical event (Fearn-Banks, 2007). In a crisis, information resources are not easily available, there is pressure to respond to the stressful situation and every stakeholder of the organization such as customers, vendors, employees, or media demands relevant information. Hence having an efficient communication system is an important element of effective management. With advanced technology and the 
growing importance of media the organization's employees at all levels may face direct questioning from media, news channels, or on a personal level from friends or family members during the crisis. During such situations, due to high-stress levels, all the communication systems break down and people get incorrect and contradictory information. Hence, it is very important for an organization to develop a better communication platform and strategy to handle official communication during a crisis.

This research paper is focused on the comparative study of the communication approaches followed by Cadbury and McDonald's during two periods in which the companies were handling a crisis. The aim of the study is to understand as well as to develop a crisis communication plan for successful crisis communication management.

\section{Literature review}

There are many books on crisis communication and crisis management, but there is no particular accepted definition of a crisis. Coombs (2014) differentiates crisis as organizational crisis and disaster. According to him, disasters are sudden large-scale events which can generate organizational crises and many government units need to respond. Coombs (2014, pp. 2-3) defines crisis as "the perception of an unpredictable event that threatens important expectancies of stakeholders related to health, safety, environmental, and economic issues, and can seriously impact an organization's performance and generate negative outcomes". Ulmer et al. (2014, p. 7) further defined organizational crisis as "a specific, unexpected, and non-routine event or series of events that create high levels of uncertainty and simultaneously present an organization with both opportunities for and threats to its high-priority goals".

Crisis management comprises actions such as prevention, preparation, response (communication) and revision. Many of the researchers who studied crisis communication (e.g., Huang, 2006) got to the conclusion that crisis communication plays an important role in a successful crisis management process. According to Benoit (1995) crisis communication or organizational response to the crisis situation decides the success of a crisis management plan.

Crisis communication can be thought of as a public relation activity intended to take care of an organization's image and reputation during crisis events. It includes the official communication from the organization with any media inquiry, legal entity, and government representative regarding any ethical, legal or financial issue regarding the organization. The motto of crisis communication during disaster or crisis is to help the organization achieve the regular day-to-day work mode and keep the information flowing within and outside the organization.

Crisis communication may be expressed as a technique or strategy to mend the image of an organization after crises (Coombs, 1998). Scholars have recommended many solutions to managing crisis including the impression management strategy designed by Allen and Caillouet (1994), the information strategy conceived by Sturge (1994) and the image restoration theory by Benoit $(1995,1997)$. Theory says that the official communication from an organization should be goal oriented and the main goal of the communication should be the preservation of a constructive reputation of the organization.

Some of the major strategies in image restoration theory are: denial, evasion of responsibility, reducing the offensiveness of event, corrective action (taking actual 
measures to correct the issues, and mortification (clarification is provided by the accused about the problem and after taking responsibility for the cause of the problem the accused asks for forgiveness). This theory provides the options available for the organization in regards to the type of communication strategy to be implemented to protect or sustain the reputation of the organization (Benoit, 2005).

Coombs (1995) divided crises into four types depending on the origin of the crisis. It can be caused by intentional or unintentional action and the source can be internal, i.e. within the organization, or any other external source. Crisis communication is usually decided based on the nature of the crisis, but it is important for every organization to have a crisis communication plan ready to deal with adverse crisis situations.

A crisis communication plan will not guarantee that the company will successfully handle the crisis situation and save their reputation, but literature supports that crisis communication plans play an important role (Jaques, 2007). It is also important to check the limitations of the crisis communication plan. The main issue associated with a crisis is that it is unpredictable hence difficult for an organization to get prepared for it (Schoenberg, 2005). It is also observed that a proper crisis communication plan can still fail due to inadequate leadership support (Schoenberg, 2005).

\section{The importance of crisis communication}

Crisis communication is important for an organization because it helps: (a) improve the brand image of the company after a critical situation on the market, (b) gain the trust of the customers and assure them the security and faith, (c) get support from the existing employees and keep a high reputation on the market for upcoming recruitment, (d) avoid legal issues or violent actions from the public against the company, (e) sustain and grow in the same industry after crisis, (f) avoid ambiguity and misconceptions in interactions with stakeholders.

The literature on crisis communication comprises combinations of suggestions and recommendations intended to help an organization plan, prepare and act for effective crisis management (Mitroff, 2002). The approach of the pre-planning for the crisis is supported by Jaques (2008) who states that various crisis theories claim that organizations with crisis communication programs are better prepared to manage crises, and so suffer less damage such experiences. Diligence is also an essential aspect of effective crisis communication. Communications strategies will only be successful if all avenues are explored and public relations practitioners are prepared for an unexpected crisis (Fearn-Banks, 2007).

Crisis communication becomes effective only when the organization under crisis responds to the situation at once. Cincotta (2005) suggested that organizations should follow a proactive approach to handle the crisis situation appropriately and convey their stance efficiently to their stakeholders and customers. Johnson and Zawawi (2002) observed that it was difficult to remove the negative perceptions of the market about an organization after the crisis broke out due to lack of anticipation and preparation. Matera and Artigue (2000) recommend "if management regards public relations functions as important, then the chances are good that a corporation can successfully emerge from disaster" (p. 216). 
Seymour and Moore's (2000, p. 99) suggested a communication framework for internal and external communication in a crisis called the 5Cs: care (communication should show that the company cares about the problem and empathizes with those affected), commitment (the company must declare and act to show their will to solve the problem, find the cause, and prevent it from happening again), consistency and coherence (all communication by spokespeople should say the same thing), clarity (crisis problems should be clearly explained and should clarify the company's position and actions).

Although crisis communication plans have many limitations, they still prove to be important for organizations as they assure that the organizations act during a crisis (Massey and Larsen, 2006). There is no 'one size fits all' crisis response for all situations, but the pattern has to be researched to guide an organization towards more effective crisis communication (Heath, 2006). Jaques (2008) stated that one of the best ways to develop a crisis communication plan is to learn from the crisis situations faced by other organizations. We can also develop an effective crisis communication plan by studying the best practices used by different organization in crisis communication (Seeger, 2006).

\section{Research methodology}

This exploratory study is based on a qualitative analysis of two case studies of well-known companies: Cadbury and McDonald's. We wanted to select big multinational companies as they would be more likely to have proper crisis communication preparedness. We also selected two crisis situations in India, a developing country which has a different culture compared to the developed countries where Cadbury and McDonalds were founded. Analyzing the crisis communication of these companies would highlight the crisis communication strategies of established companies and emphasize how they factor in the cultural and social differences in their strategy.

Data was collected from articles regarding the crisis communication of the companies Cadbury and McDonald's during crisis published in newspapers or on news sites e.g. The Times of India, Business Standard, rediff.com and BBC news. The data was collected and analyzed from articles published in 2001 for McDonalds and in 2003-2004 for Cadbury following the controversy.

The data was analyzed using content analysis to bring out the important factors that should be taken care of during crisis communication. Since these incidents took place more than 10 years ago, this gave us enough room to analyze the crisis communication efforts and the after effects.

\section{Cadbury crisis communication}

Cadbury faced a huge crisis in October 2003, due to worms found in the Dairy Milk chocolate in some places in India. This situation arose in Maharashtra where customers complained about finding worms in the Dairy Milk packets just before the festival of Diwali, a season of high sales for Cadbury and its product Dairy Milk.

The company took very effective moves to overcome this crisis and crisis communication was efficiently used. We analyzed eight newspaper articles containing statements made by the company during the crisis of worms in the Dairy Milk using content analysis in order to establish the important factors of crisis (see Table 1). 
Table 1. Content analysis of the statements from Cadbury

\begin{tabular}{|l|l|l|}
\hline Statement & Theme & Category \\
\hline $\begin{array}{l}\text { Cadbury issued a statement that the infestation was not } \\
\text { possible at the manufacturing stage and poor storage at } \\
\text { the retailers was the most likely cause of the reported } \\
\text { case of worms. }\end{array}$ & $\begin{array}{l}\text { Denied the } \\
\text { responsibility of crisis }\end{array}$ & Defense \\
\hline $\begin{array}{l}\text { In October Cadbury launched the project 'Vishwas' - an } \\
\text { education initiative covering 190,000 retailers in key } \\
\text { states. }\end{array}$ & $\begin{array}{l}\text { Quick action to back } \\
\text { earlier statement }\end{array}$ & Recovery action \\
\hline $\begin{array}{l}\text { We believe that to be a responsible company, consumers } \\
\text { need to have complete faith in our products. }\end{array}$ & $\begin{array}{l}\text { Regaining the trust of } \\
\text { the customer }\end{array}$ & Focus on customers \\
\hline $\begin{array}{l}\text { By investing up to Rs 15 crore (Rs 150 million) in } \\
\text { imported machinery, Cadbury's revamped the packaging } \\
\text { of Dairy Milk. The metallic poly-flow was costlier by 10- } \\
15 \text { per cent, but Cadbury didn't hike the pack price. }\end{array}$ & $\begin{array}{l}\text { Change in packaging } \\
\text { to avoid future crisis }\end{array}$ & $\begin{array}{l}\text { Investment for the } \\
\text { future }\end{array}$ \\
\hline $\begin{array}{l}\text { Cadbury's roped in brand ambassador Amitabh } \\
\text { Bachchan to do some heavy duty endorsement putting } \\
\text { his personal equity on the line for the brand. }\end{array}$ & $\begin{array}{l}\text { Marketing and convey } \\
\text { about the safety of the } \\
\text { product. }\end{array}$ & Advertisement \\
\hline
\end{tabular}

Source: Authors' own research.

The company followed a five-step strategy of crisis communication which included the first step: claiming that the crisis had occurred due to storage issues and attempting to save the image of the company in the market using the defense approach. But the Food and Drug Administration (FDA) alleged that it was either improper packaging or a manufacturing defect combined with unhygienic storage conditions which caused the products to get infested. Allegations and counter-allegations took place and this negative publicity decreased Cadbury's sales by 30 per cent in the festive season which normally resulted in 15 per cent rise (Vaid, 2006).

To get things back on track and as a back up to the first step, the company started an education program for the retailers so that the storage end would be secured. Due to many allegations from the FDA regarding the packaging of the product, the company quickly changed the communication strategy. Cadbury took the initiative and improved the packaging. It conveyed to the consumers that if the crisis had occurred due to the packaging issues then the company was ready to take the responsibility and now was improving the packaging system to provide safe products to its consumers.

Cadbury conveyed many messages to regain the trust of the customers and to connect with them emotionally. Their promotional strategy was to use an iconic actor Amitabh Bachchan as a brand ambassador for the advertising campaign to ensure that people would trust the product and feel that it is safe to buy Cadbury's Dairy Milk.

The controversy affected the company badly. For the year which ended on December 2003, Cadbury's net profit fell 37 percent to Rs 456 million 1 compared to a 21 percent increase in the previous year. The sales volumes of Cadbury Dairy Milk, the flagship brand in which worms were found, declined from 68 percent in October 2003 to 64 percent in January 2004. However as a result of the company's efforts, it again went up to 65.9 percent in May 2004. Also, the value share of Cadbury which went from 73 percent in October 2003 to 69.4 percent in January 2004 again got back up to 71 percent in May

\footnotetext{
${ }^{1}$ One Dollar was equal to 66 Indian rupees as of December 2015.
} 
2004 (Zachariah, 2004). Thus, Cadbury demonstrated a really good crisis communication strategy and recovered well.

The important elements of crisis communication extracted from the Cadbury Dairy Milk worm crisis are as follows: defense, recovery action, focus on customers, investment for the future, advertisement.

\section{McDonald's crisis communication}

In 2001, there was a crisis outbreak at McDonald's, the world's largest restaurant chain. Two vegetarians sued the company accusing it of deliberately misleading its American customers regarding the use of beef extract in French fries sold in the United States, an ingredient the company described as "natural flavor" in its nutrition brochures. The issue hit the markets of McDonald's across the world. In the US, people were against McDonald's because the company hid the ingredient that had been used and mislead the vegetarian people. In India, it became a religious issue as it hurt the sentiments of vegetarians and Hindu people whereas in Europe the sales fell because of consumer concern over beef safety.

McDonald's issued the following official statements after the crisis broke out:

Table 2- Content analysis of the statements from McDonald's

\begin{tabular}{|c|c|c|}
\hline Statements & Theme & Category \\
\hline $\begin{array}{l}\text { McDonalds has never made any claims about the } \\
\text { vegetarianism of our French fries or any other product. }\end{array}$ & $\begin{array}{l}\text { Clarification that the } \\
\text { product is not vegetarian. }\end{array}$ & Clarification \\
\hline $\begin{array}{l}\text { Because it is our policy to communicate to customers, we } \\
\text { regret if customers felt that the information we provided } \\
\text { was not complete enough to meet their needs. If there } \\
\text { was confusion, we apologize. }\end{array}$ & $\begin{array}{l}\text { Public issue of the } \\
\text { company policy and } \\
\text { apologize }\end{array}$ & Apologize \\
\hline $\begin{array}{l}\text { All those interested in taking a McDonald's kitchen tour } \\
\text { can come and see for themselves how the company } \\
\text { operates. }\end{array}$ & $\begin{array}{l}\text { Involvement of the } \\
\text { customer directly }\end{array}$ & Recovery action \\
\hline
\end{tabular}

McDonald's was quick in responding to the crisis, but the public statement was negative. The company totally refused the responsibility for the crisis saying that the company had never claimed the product to be vegetarian. This communication indirectly confirmed that the French fries were not vegetarian and it was not disclosed on the ingredients list of the product. The first communication from the company regarding the crisis resulted in a huge crowd against the company which became even worse when the crisis took a religious turn in India because the cow is sacred to Hindus. Demonstrators smashed restaurant windows and smeared signs with cow dung. Many McDonald's outlets in India were shut down or were running under police protection.

The protests prompted McDonald's to run advertisements in Indian newspapers reassuring consumers that it used no animal extracts in the French fries it sold there. Soon after the company was sued by people in the US, McDonald's issued apologies to the people for inadequate information sharing about the ingredients of the French fries. Despite the negative publicity, McDonald's chose not to issue a public statement, instead carrying the apology on an obscure page on its corporate Web site. It proved very costly as the company's 2001 Summary Annual Reports showed that for the first time in 11 years, its net 
income had come down significantly from \$ 1977 million to \$ 1637 million. Ultimately McDonald's also had to agree to settle suits by paying $\$ 10$ million to vegetarian and religious groups as well as paying $\$ 4,000$ to 12 plaintiffs each in five separate lawsuits (The New York Times, March 9, 2002).

The last step of the crisis management was effective where, after the lab testing of the product, the company actually invited the customers directly into the McDonald's kitchen. They shared the process of cooking the product and the hygiene maintained to clarify all the doubts. This step helped the company to regain the confidence of the consumers and improve the sales numbers.

The important elements of the crisis communication collected through the McDonald's French fries beef crisis were as follows: clarification, apologies, and recovery action.

\section{Findings}

The analysis of the statements issued by both the companies- Cadbury and McDonald's showed the diverse ways in which these companies approached crisis communication. Cadbury initially tried to deny the responsibility, but when it understood that it was not working, it came up with a series of concrete steps. This included steps like the education initiative for retailers to secure the storage end, investment in packaging, communication with the customers, taking up responsibility and being accountable. Cadbury also brought in a trustworthy and respected Indian movie actor, Amitabh Bachchan, to regain the trust of consumers. It followed the image restoration theory described by Benoit $(1995,1997)$ to a large extent. In the end, the company managed to connect with the customers and gained back their confidence as well as their share.

On the other hand, although McDonald's came up with a quick response, it was not the appropriate one. The fast food chain ended up confessing that the product was not vegetarian. Because of that, the situation worsened and escalated and took a turn for the worse when it became a religious issue. The company was sued by many people and its restaurants were attacked. McDonald's had no option but to apologize and to settle the law suits by paying a lot of money. Finally, to win back the trust in such a sensitive issue, it involved the customers directly. Overall Cadbury handled the issue better. McDonald's took time to get it right and ended up with losses in settling suits too, but in the end both managed to gain back the consumer's trust by taking the appropriate steps.

The findings and recommendations after the study of the two crisis cases can be summarized as: (a) the statement issued by organizations during a crisis should be clear and not offensive.; (b) the company should respond to the crisis as quickly as possible to avoid loss in terms of the decline in sales number; (c) Advertisement is the best way to convey the message across the world because the crisis situation raised in one market can soon spread to other markets; (d) the company has to connect with the consumer on emotional grounds because the crisis breaks down the faith of the consumer in the company; (e) sensitive issues like religious background or health safety should be handled carefully to avoid negative publicity; (f) the communication from the company should be in the direction of creating a positive image of the company and should not hurt the sentiments of the consumers; (g) care has to be conveyed properly through the official communication of the company; (h) crisis communication needs to be varied in accordance 
to the crisis situation; and (g) the involvement of the top management in the crisis communication is a must.

\section{Conclusions}

Crisis communication is very important during a crisis situation for the company. It should be directed towards creating a positive image of the company after the crisis. Quick responses, positive communication and immediate recovery actions are essential during a crisis. The direct involvement of the customers, one to one talk with the customers to solve their queries and emotional bonding can prove to be important elements of crisis communication. Crisis communication should be clear and free from ambiguity. It is important to learn from the past hence organizations should study past crisis situations, the crisis communication tools used and should proactively create a crisis communication plan for their organization.

This paper will help managers understand the different real time scenarios and the actions that have been taken by reputed brands during a crisis. It clarifies the dos and don'ts of crisis communication and how the company can regain its reputation on the market after a crisis. This paper will also help them understand the consequences of the official communication from the company during a crisis and its impact on the sales of the company. It will be useful to learn from the crisis communication implemented by companies and take preventive measures in the future to avoid losses due to crisis.

\section{References}

Allen, M.W. and Caillouet, R.H. (1994),"Legitimate endeavors: Impression management strategies used by an organization in crisis", Communication Monographs, Vol. 61, No. 1, pp. 44-62.

Benoit, W.L. (1995), Accounts, excuses, and apologies: A theory of image restoration, State University of New York Press, Albany.

Benoit, W.L. (1997),“Image repair discourse and crisis communication”, Public Relations Review, Vol. 23, No. 2, pp. 177-186.

Benoit, W.L. (2005), "Image restoration theory”, in R.L. Heath (Ed.), Encyclopedia of public relations, Sage, Thousand Oaks, CA, Vol. 1, No. 4, pp. 407-410.

Benoit, W.L. and Brinson, S.L. (1994),"AT\&T: Apologies are not enough”, Communication Quarterly, Vol. 42, No. 1, pp. 75-88.

Benoit, W.L. and Brinson, S.L. (1999), "Queen Elizabeth's image repair discourse: Insensitive royal or compassionate queen”, Public Relations Review, Vol. 25, No. 2, pp. $145-156$.

Benoit, W. L. and Pang, A. (2008), Crisis communication and image repair discourse, Pearson, New York.

Coombs, W.T. (1995),"Choosing the right words the development of guidelines for the selection of the 'appropriate' crisis-response strategies", Management Communication Quarterly, Vol. 8, No. 4, pp. 447-476.

Coombs, W.T. (1998), "An analytic framework for crisis situations: Better responses from a better understanding of the situation", Journal of Public Relations Research, Vol. 10, No. 3, pp. 177-191.

Coombs, W.T. (1999),"Information and compassion in crisis responses: A test of their effects”, Journal of Public Relations Research, Vol. 11, No. 2, pp. 125-142. 
MMCKS Coombs, W.T. (2014), Ongoing crisis communication: Planning, managing, and responding, Sage Publications.

Cincotta, K. (2005), "Less fluff more facts, industry learns”, B\&T: News, October 31, available at: www.bandt.com.au/news/bd/0c037bbd.asp (Accessed June 12, 2015).

Fearn-Banks, K. (2007), Crisis communications: A casebook approach, 3rd Edition, Lawrence Erlbaum Associates, New Jersey.

Heath, R.L. (2006),“Best practices in crisis communication: Evolution of practice through research", Journal of Applied Communication Research, Vol. 34, No .3, pp. 245-248.

Vaid, M. (2006),"How Cadbury's won the battle of worms", Rediff India Abroad, December 27, 2006, available at: www.rediff.com/money/2006/dec/24cad.htm (Accessed August 31, 2015).

Huang, Y.H. (2006),“Crisis situation, communication strategies, and media coverage: A multi case study revisiting the communicative response model", Communication Research, Vol. 33, No. 3, pp. 180-205.

Jaques, T. (2007),"Issue management and crisis management: An integrated, non-linear relational construct", Public Relations Review, Vol. 33, No. 2, pp. 147-157.

Johnson, J. and Zawawi, C. (Eds.) (2002), Public relations: Theory and practice, Allen \& Unwin, Sydney.

The New York Times (2002),"McDonald's to settle suits on beef tallow in french fries", March 9, 2002, available at: www.nytimes.com/2002/03/09/us/mcdonald-s-tosettle-suits-on-beef-tallow-in-french-fries.html (Accessed August 31, 2015).

Massey, J.E. and Larsen, J.P. (2006),“Crisis management in real time: How to successfully plan for and respond to a crisis", Journal of Promotion Management, Vol. 12, No. 3/4, pp. 63-86.

Matera, F. and Artigue, R. (2000), Public relations campaigns and techniques: Building bridge into the 21st century, Allyn and Bacon, Needham Heights.

Mitroff, I.I. (2002),“Crisis learning: The lessons of failure”, The Futurist, Vol. 36, No. 5, pp. 19-21.

Mitroff, I.I. and Pauchant, T.C. (1990), We're so big and powerful nothing bad can happen to us: An investigation of America's crisis-prone corporations, Birch Lane, New York.

Schoenberg, A. (2005),"Do crisis plans matter? A new perspective on leading during a crisis", Public Relations Quarterly, Vol. 50, No. 1, pp. 2-6.

Seeger, M.W. (2006),"Best practices in crisis communication: An expert panel process", Journal of Applied Communication Research, Vol. 34, No. 3, pp. 232-244.

Seymour, M. and Moore, S. (2000), Effective crisis management: Worldwide principles and practice, Cassell, London.

Sturges, D.L. (1994), “Communicating through crisis”, Management Communication Quarterly, Vol. 7, No. 3, pp. 297-316.

Ulmer, R.R., Sellnow, T.L. and Seeger, M.W. (2014), Effective crisis communication: Moving from crisis to opportunity, Sage Publications.

Zachariah, R. (2004),"Cadbury recovers from worm shock", Business Standard, available at: www.business-standard.com/article/companies/cadbury-recovers-from-wormshock-104070301003_1.html (Accessed August 31, 2015). 